\title{
Analysis and framework for agricultural supply chain improvement: a case study of california papaya in cikarang
}

Johan K. Runtuk*, Anstasia L. Maukar

Department of Industrial Engineering, Faculty of Engineering, Universitas Presiden, Jababeka Education Park, Bekasi, Jawa Barat 17550, Indonesia

\begin{tabular}{l} 
ARTICLE INFORMATION \\
\hline Article history: \\
Received: April 25, 2019 \\
Revised: June, 27, 2019 \\
Accepted: December 16, 2019 \\
\hline
\end{tabular}

Keywords:

California Papaya

Food Supply Chain

Network

Packaging

Waste

*Corresponding Author

Johan K. Runtuk

E-mail: johan.runtuk@president.ac.id

\section{A B S T R A C T}

Excessive waste is one of the problems in the food supply chain system. This study aims to identify supply chain players, map, and reduce waste that occurs in the Papaya California agribusiness supply chain process in Cikarang, Bekasi. Data collection was obtained from the results of field studies and interviews with parties involved in the supply chain such as farmers, distributors, retailers, and consumers. Increasing the effectiveness of Papaya's supply chain network is by improving the quality of packaging (modified atmosphere packaging (MAP), smart packaging, active packaging, and intelligent packaging), sharing data among chain players supply, implement refrigeration and monitor transportation technology and promote the long term. Good coordination between parties involved in the Papaya supply chain has a significant role in creating an effective and efficient supply chain system.

This is an open-access article under the CC-BY-NC-SA license.

\section{INTRODUCTION}

Indonesia has a tropical climate, with an excellent opportunity for the development of fruits cultivation, mainly tropical fruits. In the last few years, fruit products have experienced an increase in demand as healthy lifestyles have begun to increase [1]. Increasing demand for the fruit opens opportunities for the improvement of the fruit so that Indonesian agribusiness to be able to compete with other countries, especially in dealing with free trade.

One of the tropical fruits that are very popular in Indonesia is papaya. Papaya (Carica papaya L.) is a plant that originated from southern Mexico and the northern part of South America and is now widespread throughout the world. Papaya is a plant from herbaceous family Caricaceae and a horticultural commodity that has high economic value. Papaya is an agri-fresh product which is an essential part of the world economy and is a raw material for many industries. [2].

The supply chain management of agri-fresh products constitutes the processes from production to delivery of the agri-fresh product. Fruit supply chain management is complex compared to other supply chain management due to the perishable nature of the product [3], [4], the instability of weather [5], high fluctuations in demand, and price volatility [6], [7]. Thus, it increases consumer concerns for food safety, dependence on climate conditions [8], and food spoilage [9]. Management 
of fruit management is increasingly difficult with worldwide demand and supply [10].

The agri-food supply chain is related to all processes, from production to the consumption of fresh products (fruits, vegetables, etc.) [11], [12]. The logistics should be deliberately considered, especially for perishable agricultural products in the agri-food supply chain [13]. The primary concern for agri-fresh supply chain management is the postharvest wastage [14], and the cost related to food waste is enormous [15].

Research on the Papaya supply chain in Indonesia was conducted by Rizqiah, \& Slamet [16], who reviewed the SWOT analysis to develop Papaya productivity. Calina papaya quality improvement strategies by improving product quality, production capacity, and security guarantees by expanding the distribution network. Papaya product quality that influences the buyer's decision is the level of cleanliness of the skin, the level of sweetness, and the suitability of the price [17].

This study tries to continue previous research [16] by analyzing the waste that occurs during the papaya supply chain process. Waste selection in this study because waste has a significant cost contributor to the supply chain network with perishable goods [15]. Waste that occurs due to inefficiency in handling the process, storage, and transportation process. Collaboration between parties in the supply chain has a significant role in creating an efficient supply chain system [18].

Based on the observation in several traditional markets in Cikarang, the Papaya California supply chain has much waste. The circumstances that causing the waste in the Papaya California food supply chain network are lack of packaging knowledge, lack of communication of food supply chain players, inaccurate sales forecasting, long transport distance, weather-related loss, and the last is lack of transparency along the food supply chain.

This research identifies all stages in the Papaya California supply chain in Cikarang. Then, the supply chain network of Papaya California is mapped. Recommendations to improve the distribution flow as well as communication and information flow, are given. Finally, the framework to reduce waste is proposed.

\section{RESEARCH METHODS}

This study analyzes the Papaya supply chain network in Cibitung Central Market, Bekasi. The study was conducted by conducting interviews with farmers, distributors, retailers, and consumers. Interviews were conducted through faceto-face meetings and telephone interviews.

After the field survey and interview are carried out, the second step is to identify the problem based on survey data or the results of the conversation. These problems form the basis of setting research objectives that focus on the analysis of the California Papaya supply chain network in Cikarang.

Qualitative semi-structured interviews with all stages collected data in the California Papaya supply chain in Cikarang. Interviews were conducted with representatives of each step of the supply chain, who were willing to provide deeper and broader information. After data is collected, the data is transcribed and analyzed to obtain supply chain network improvements related to resources, product processing, distribution channels, relationships with others, information flow, and incentive systems. The final stage provides recommendations for improving supply chains to enhance the profitability of papaya supply chains.

\section{RESULTS AND DISCUSSION}

\section{The Interview Results}

Farmer's Interview Result

To be able to get the farmers of papaya, we conducted interviews with several papaya distributors in Cibitung Central Market, Bekasi, West Java. Based on interview results, California Papaya supplies came from two different cities, Lampung and Bogor. These cities are suitable for papaya fruit plantations because they still have a natural environment and are close to the national capital. Because the harvest season of California papaya is uncertain, Bogor farmers cannot supply continuously to Cibitung Central Market. Thus, Cibitung Central Market also received papaya from farmers of Lampung.

Fifteen years of struggling in the business of California Papaya is not easy for farmers that originated in Lampung. Since the number of 
players increases, currently, he should still keep the quality of seeds and fruits which plant near his home. Initially, not too many players who want to wrest California Papaya for the business, but as time went on, the population about looking at business opportunities of California Papaya business opportunity had bright prospects. An easy way of cultivation, the age waits of harvest time, is short and can be planted in all types of land made the reason for population began to cultivate a business of California Papaya.

Giving discounts under certain conditions is their attempt to maintain good relationships and maintain communication with customers. Besides, they entered into a contractual agreement with the distributor for the certainty of the post-harvest price. The contract facilitates communication between the two parties and reduces fraud. The ability to collaborate with the supplier level has been able to create a more responsive and efficient supply chain [19].

\section{Distributor's Interview Result}

Based on interviews, all distributors get supplies from farmers from Lampung and Bogor. Most of the distributors in the wholesale market Cibitung purchase California papaya from farmers in Lampung. Some of the papaya supply comes from papaya farmers in Bogor, but Papaya production in Bogor has a limited long-term supply chain.

To get the California Papaya from Lampung, they need 13 hours to ship the papaya from Lampung to Cibitung. They can get the highest demand for around 10 tons per day. All of the distributor's process or convert the California Papaya in their store. They save the California Papaya into a wooden box and add some newspapers into the box before distribute it to their customers. Their customers come from Karawang Market, Cikampek Market, SGC Market in Cikarang, Barokah Fruit Stall, and Kalingga Fruit Stall.

A direct-distribution channel is a method of selling that allows a producer to move goods straight to a customer without the involvement of a middleman. All distributors use direct distribution; they sell their product directly to the customer in their store. Build a strong relationship with the customer is essential. The way how UD Buah Segar builds a strong relationship with the customer is using a discount. The discount will be offered to the customer who buys the minimum order or when there is a special event. The way how UD Makmur Jaya builds relationship customers is by giving a special price to the customer. Still, for UD Bangkit Lagi, they do not do specific actions to build a relationship with the customer.

Distributors coordinate their information flow with communicating and recheck to their suppliers to assure everything is goiung well. All of the distributors set a communication system to their partner to set off the incentive system. The summary of the interview can be seen in Table 1 .

Table 1. Distributor's summary interview result

\begin{tabular}{|c|c|c|c|}
\hline & $\begin{array}{c}\text { UD bangkit } \\
\text { lagi }\end{array}$ & $\begin{array}{l}\text { UD buah } \\
\text { segar }\end{array}$ & $\begin{array}{c}\text { UD makmur } \\
\text { jaya }\end{array}$ \\
\hline Source & $\begin{array}{l}\text { Bogor } \& \\
\text { Lampung }\end{array}$ & $\begin{array}{l}\text { Bogor \& } \\
\text { Lampung }\end{array}$ & $\begin{array}{l}\text { Bogor } \quad \& \\
\text { Lampung }\end{array}$ \\
\hline $\begin{array}{l}\text { Process } \\
\text { place }\end{array}$ & On the spot & On the spot & On the spot \\
\hline $\begin{array}{l}\text { Type } \\
\text { channel } \\
\text { distribution }\end{array}$ & $\begin{array}{l}\text { Direct } \\
\text { channel } \\
\text { distribution }\end{array}$ & $\begin{array}{l}\text { Direct } \\
\text { channel } \\
\text { distribution }\end{array}$ & $\begin{array}{l}\text { Direct } \\
\text { channel } \\
\text { distribution }\end{array}$ \\
\hline $\begin{array}{l}\text { How to build } \\
\text { a strong } \\
\text { relationship } \\
\text { with } \\
\text { customer }\end{array}$ & Do nothing & Discount & Special price \\
\hline $\begin{array}{l}\text { Information } \\
\text { flow }\end{array}$ & $\begin{array}{l}\text { Always } \\
\text { recheck }\end{array}$ & $\begin{array}{l}\text { Always } \\
\text { recheck }\end{array}$ & $\begin{array}{l}\text { Always } \\
\text { recheck }\end{array}$ \\
\hline $\begin{array}{l}\text { Logistics } \\
\text { structure }\end{array}$ & Truck \& ship & Truck \& ship & Truck \& ship \\
\hline $\begin{array}{l}\text { Shipment } \\
\text { time }\end{array}$ & 13 hours & 15 hours & 15 hours \\
\hline Customer & $\begin{array}{l}\text { Karawang } \\
\text { Market } \\
\text { Cikampek } \\
\text { Market } \\
\text { SGC Market } \\
\text { Kalingga } \\
\text { Fruit Stall } \\
\end{array}$ & $\begin{array}{l}\text { Karawang } \\
\text { Market } \\
\text { Cikampek } \\
\text { Market } \\
\text { SGC Market } \\
\text { Barokah } \\
\text { Fruit Stall } \\
\end{array}$ & $\begin{array}{l}\text { Karawang } \\
\text { Market } \\
\text { Cikampek } \\
\text { Market SGC } \\
\text { Market }\end{array}$ \\
\hline
\end{tabular}

\section{Retailer's Interview Result}

There are three retailers of California Papaya in Cikarang that interviewed by the researcher, which are Fresh Fruit Kalingga, Barokah, and Pasimal Market. Based on these interviews, data gathered related to California Papaya are the source of those retailers, how they process the papaya, distribution system, the relationship with customer and distributor, information flow, logistics structure, and incentive system.

All retailers purchase California Papaya from distributors in Cibitung Central Market every day. Depending on stock and customer demand, retailers directly pick the California Papaya. As 
perishable goods, retailers do not want to take the risk of buying California Papaya in high volume.

Each retailer has a way to build its relationship with other parties. For Fresh Fruit Kalingga, they develop their relationship with their suppliers through good communication. They also try to build their relationship with their customers by giving the customer an excellent service. Barokah builds their relationship with distribution through a trust to the single distributor. They also try to provide good quality of California Papaya to attract customer and make the customer choose to buy in their store than others, that effort hopes can build a strong relationship with the customer. For another retailer, Pasimal Market, they create a strong relationship with their supplier through good communication and always buy in their store. They also build a strong relationship with their customers through their excellent services, and costumer can bargain in that store.

\section{Consumer's Interview Result}

Based on consumer demands, California Papaya is classified into several grades, which are:

a. Grade A ( $1-2.5 \mathrm{~kg}$, has a long and oval shape, smooth skin, orange-red flesh, sweet flavor, ripeness level $80-90 \%$, pesticide-free).

b. Grade B $(0.5-0.9 \mathrm{~kg}$, has long and oval shape, less scratch on the skin, orange flesh, less sweet flavor, ripeness level 50-80\%).

c. Grade $\mathrm{C}$ (the remaining from the selection of Grade A \& B).

d. Grade $O$ (has a round shape).

e. Grade R (rejected).

Each market has different consumer demand. Supermarket usually prefers grade A, fruit stall prefers grade $\mathrm{B}$, while the preference of traditional market is ranging from $\mathrm{A}$ : $\mathrm{B}$ : $\mathrm{C}$. Grade $\mathrm{R}$ and $\mathrm{O}$ are preferred by manufacturers.

\section{Understanding the Consumer}

Principle of the understanding customer and consumer call for agricultural producers to understand the specifications of the type of consumers preferred California Papaya (consumer preferences). By following consumer preferences, the farmers will be expected to maintain the quality of papaya. It can be achieved by implementing a Standard Operating Procedure (SOP) to produce papaya that can fulfill the market request. Thus, the research was carried out to find the preference profile of California Papaya consumers (Table 2).

Table 2. Summary of customer needs

\begin{tabular}{llc}
\hline \multicolumn{1}{c}{ Name } & \multicolumn{1}{c}{ Criteria } & Percentage \\
\hline Grade of \\
california \\
papaya & Grade A & $60 \%$ \\
Fresh & Grade B & $40 \%$ \\
colour & Orange, red flesh & $30 \%$ \\
& Orange flesh & $50 \%$ \\
& Orange yellow flesh & $20 \%$ \\
Size & Big & $20 \%$ \\
& Medium & $60 \%$ \\
& Small & $20 \%$ \\
& Smooth skin & $50 \%$ \\
Type of & Little bump or & $25 \%$ \\
skin & scratches & \\
& Manybump or & $25 \%$ \\
& scratches & \\
Price & Grade A & Rp 5.000,- \\
& Grade B & Rp 4.000,- \\
\hline
\end{tabular}

Some suggestions to respond to consumer demand, there are several requirements for farmers which are:

a. Harvesting Papaya California with a maturity level of about $75 \%$.

b. Performing regular maintenance trimming and thinning of fruit for large fruits.

c. Choosing Papaya California varieties with sweet flavor.

d. Controlling the packaging system, to make a smooth skin without bumps or scratches and controlling the HPT in both the tree and the fruit so that the fruit is not black and dull.

\section{Supply Chain Network of California Papaya in Cikarang}

Based on the interview and filed study, the supply chain network of Papaya California in Cikarang can be simplified simplified into one dominant channel, as illustrated in Fig, 1. There are two producers of California Papaya, farmers that come from Lampung and Bogor. The estimated profit margin obtained by farmers from Lampung is $40 \%$, while the profit margin earned by farmers from Bogor reached $60 \%$. Profit margin is considered feasible for farmers and other players in the supply chain if the percentage of margin is higher than $30 \%$. Based on that provision, it could be seen that profit margin received by the suppliers, distributors, and retailers are worth since the 
percentage of profit is above $30 \%$. However, the benefit received by the farmers is the smallest compared with the advantages enjoyed by other players in the supply chain, but it is still within a reasonable limit. A simple illustration of the distribution of profit margins that occur in the California Papaya supply chain is farmers with a $30 \%$ profit rate, $20 \%$ distributor, and $50 \%$ retailer.

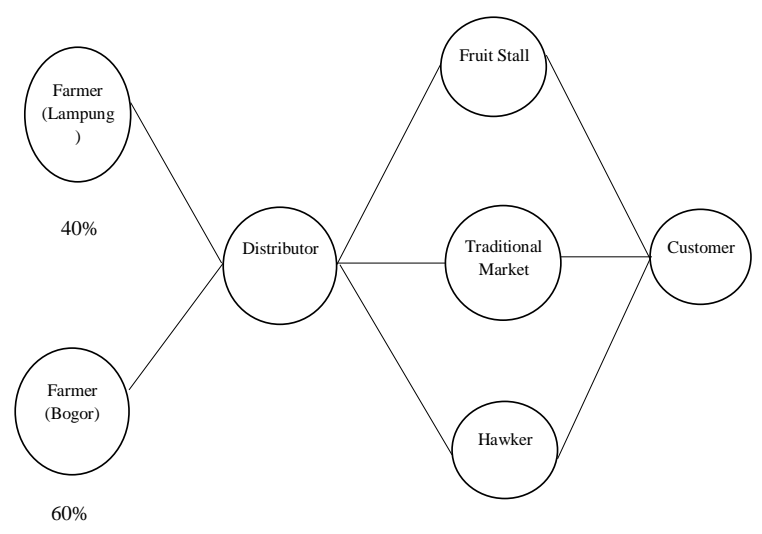

Fig. 1. Supply chain of california papaya

Increasing the effectiveness of the Papaya supply chain system can be done by improving distribution flow, communication, and information flow, and reducing waste. Several improvements will be proposed related to California Papaya distribution flow from farmers in Lampung and Bogor to end customers. First, it is needed to determine the harvesting schedule of California Papaya. Second, improving transportation routes so that product flow becomes smoother. Third, it is required a packing house as a place of temporary gathering, sorting or grading, and packaging of California Papaya. Fourth is the establishment and empowerment of the agribusiness terminal. Fifth, encourage the existence of cool chain product transportation. Sixth is the improvement of road quality to the farm areas so that the trucks can enter the village area quickly. And the last is the revitalization of the local harbor by building cold storages and other supporting infrastructure.

There are some solutions to make smooth communication and information flow, such as network optimization, visibility, and communication. Network optimization, along with collaboration, optimization is playing an essential part in speeding up California Papaya supply chains.
Retailers, distributors, or producers need to review together about the Papaya California product distribution network and realign as necessary to increase speed and be responsive to variations in supply or demand.

The initiation of communication networks can be carried out by forming a tripartite meeting forum (three parties) such as Farmers (represented by POKTAN and GAPOKTAN), Distributor and Retailer. The meetings periodically as needed to discuss the quality of California Papaya, which fulfills the customer demand and the appropriate price for each party. It is necessary to gather information related to customer needs and continuity from the market to make a smooth communication of tripartite. Also, it is needed a Papaya Center that can act as PINSAR. PINSAR has the task of collecting the market information from downstream market party and upstream market party or one-way information. Besides, PINSAR also needs to dig up the market information between each upstream market parties or two-way information. There will be market information disclosure that can be accessed by all parties to be negotiated by market party and farmers through PINSAR role.

Product demand and reduction of food losses and waste along the supply chain is one of the critical challenges in this era. Food loss and waste is not the consumer's responsibility only. A considerable amount of food that gets wasted is in the postharvest supply chain process. Thus the supply chain process should be maintained efficiently. Measures to reduce food loss and waste in the food supply chain can be categorized into five different groups namely harvesting and post-harvesting, retailing, transportation, tracking and processing (Table 3) based on research developed by Nitsche et, al [20]

One of the main contributions to reducing food loss and waste is the packaging concept. Innovative packaging can reduce waste and increase product shelf life [20], [21]. Good packaging also has an impact on the product that lasts longer and is not easily damaged. Several food packaging technologies can be used, including master packaging [22], active packaging [23], or smart packaging [24]. 
Table 3. Main causes of loss/ waste in the food supply chain

\begin{tabular}{|c|c|c|}
\hline Area of causes & \multicolumn{2}{|c|}{ causes } \\
\hline $\begin{array}{l}\text { Harvesting and } \\
\text { post-harvesting }\end{array}$ & $\begin{array}{l}\text { Weather-related loos } \\
\text { Suboptimal harvest period } \\
\text { Damage of crops } \\
\text { Inadequate infrastructure }\end{array}$ & $\begin{array}{l}\text { Defective harvesting equipment } \\
\text { Lack of qualified personnel } \\
\text { Overproduction } \\
\text { Low level of automation }\end{array}$ \\
\hline Retail & $\begin{array}{l}\text { Lack of cooling system } \\
\text { Inappropriately equipped storage and sales } \\
\text { areas } \\
\text { Unhygienic conditions }\end{array}$ & $\begin{array}{l}\text { Uncertainties according to date } \\
\text { indications } \\
\text { Inefficient optimization efforts, } \\
\text { promotion, and discounts } \\
\text { Inaccurate sales forecasts }\end{array}$ \\
\hline Transportation & $\begin{array}{l}\text { Inadequate infrastructure } \\
\text { Inappropriately equipped transport } \\
\text { vehicles } \\
\text { Low transportation safety of perishable } \\
\text { goods } \\
\text { Unreliable transport packaging } \\
\text { Inappropriate load securing }\end{array}$ & $\begin{array}{l}\text { Long throughput times } \\
\text { Long transport distances delivery } \\
\text { delays } \\
\text { Overloading of terminal insufficient } \\
\text { temperature measurements }\end{array}$ \\
\hline Packaging & $\begin{array}{l}\text { Lack of packaging knowledge } \\
\text { Inappropriate packaging for transportation } \\
\text { and storage } \\
\text { Ineffective design design }\end{array}$ & $\begin{array}{l}\text { Large packaging units } \\
\text { Defective packaging }\end{array}$ \\
\hline Process & $\begin{array}{l}\text { Lack of a holistic view of value-adding } \\
\text { processes in FSC due to egocentric profit } \\
\text { optimization } \\
\text { Lack of communication between FSC } \\
\text { actors } \\
\text { Inefficient processing process } \\
\text { Lack of transparency along the FSC }\end{array}$ & $\begin{array}{l}\text { The high complexity of the value- } \\
\text { adding process } \\
\text { Lack of a holistic view of value- } \\
\text { adding processes in FSC } \\
\text { Lack of communication }\end{array}$ \\
\hline
\end{tabular}

Another contribution to reducing food loss and waste is packaging transport concepts and network planning. As a result of the use of packaging, the use of cooling, and monitoring technologies, the selection of transportation mode is vital. The company should choose the best ways of transportation for food.

In handling a fresh food supply chain, the distinctive characteristics of the products make requirements for speedy and accurate operations. The challenges of the processes include the addition to the incredibly short product shelf life, the diverse character of the whole fresh food group, and the physical requirements for handling and storage. Supply chain management and planning requires careful planning to maintain product availability in retail stores by minimizing wasted products.
The Papaya supply chain system is included in short supply chain lead-time allowance (SCLT) because it has a fast decay and a short service life. This system has a challenge in time management to keep products passing through the supply chain quickly. Besides, the customers in this market require short customer order lead-times (COLT), i.e., rapid replenishment. Both characteristics, SCLT and COLT, require a high response in supply chain management.

Consumer demand also needs to be analyzed carefully. Variability of consumer demand is a challenge for supply chain actors in maintaining supply stability, as is the case with promotional activities. Excellent communication from the operational level and supply chain support systems have a decisive role in maintaining an effective supply chain. One step in maintaining 
excellent communication is sharing data so that supply and demand are well controlled.

\section{CONCLUSION}

Papaya California comes from Lampung and Bogor farmers. Based on the field study and interview, there are four stages in the network design of California Papaya. The first stage is Farmers from Lampung and Bogor. Then, the second stage is California Papaya distribution from Lampung and Bogor to Distributor in Central Market, Cibitung. In Cibitung Market. Papaya California then distributes to retailers who are fruit stall, traditional market, and hawker, including UD Bangkit Lagi, UD Buah Segar, and UD Makmur Jaya, Kalingga Fruit Shop, SGC Market, Cikampek Market, and Karawang Market. Finally, Papaya California isdelivered to the final customer.

There are some problems related to waste, which are lack of packaging knowledge, lack of communication of Food Supply Chain players, inaccurate sales forecasting, long transportation distance, weather-related loss, and lack of transparency among the Food Supply Chain (FSC). Some suggestions for improving the Papaya supply chain network are modified atmosphere packaging, smart packaging, active packaging, and intelligent packaging, data sharing, cooling, and monitoring of transportation technology and long-term agreements. Further research can be performed for analyzing the proposed solution in more detail.

\section{REFERENCES}

[1] D. Yosini, "Consumer preferences on import and local fruit in Indonesia," Lucr. științifice, vol. 54, no. 2, pp. 32-37, 2011, available at: http://www.thaihalalfoods.com/upload/art icles/ID_fruit_import.pdf.

[2] M. Shukla and S. Jharkharia, "Agri-fresh produce supply chain management: a stateof-the-art literature review," Int. J. Oper. Prod. Manag., vol. 33, no. 2, pp. 114-158, Feb. 2013, doi: 10.1108/01443571311295608.

[3] W. E. Soto-Silva, E. Nadal-Roig, M. C. González-Araya, and L. M. Pla-Aragones, "Operational research models applied to the fresh fruit supply chain," Eur. J. Oper.
Res., vol. 251, no. 2, pp. 345-355, Jun. 2016, doi: 10.1016/j.ejor.2015.08.046.

[4] M. Yu and A. Nagurney, "Competitive food supply chain networks with application to fresh produce," Eur. J. Oper. Res., vol. 224, no. 2, pp. 273-282, Jan. 2013, doi: 10.1016/j.ejor.2012.07.033.

[5] N. K. Tsolakis, C. A. Keramydas, A. K. Toka, D. A. Aidonis, and E. T. Iakovou, "Agrifood supply chain management: A comprehensive hierarchical decisionmaking framework and a critical taxonomy," Biosyst. Eng., vol. 120, pp. 47-64, Apr. 2014, doi: 10.1016/j.biosystemseng.2013.10.014.

[6] L. Jraisat, M. Gotsi, and M. Bourlakis, "Drivers of information sharing and export performance in the Jordanian agri-food export supply chain," Int. Mark. Rev., vol. 30, no. 4, pp. 323-356, Sep. 2013, doi: 10.1108/IMR-03-2012-0056.

[7] T. S. Workneh, M. Azene, and S. Z. Tesfay, "A review on the integrated agrotechnology of papaya fruit," African $J$. Biotechnol., vol. 11, no. 85, pp. 1509815110, 2012, available at: https://www.ajol.info/index.php/ajb/articl e/view/129498.

[8] Y. He, H. Huang, D. Li, C. Shi, and S. J. Wu, "Quality and Operations Management in Food Supply Chains: A Literature Review," J. Food Qual., vol. 2018, pp. 114, 2018, doi: 10.1155/2018/7279491.

[9] S. Hamilton, "Agribusiness, the Family Farm, and the Politics of Technological Determinism in the Post-World War II United States," Technol. Cult., vol. 55, no. 3, pp. 560-590, 2014, doi: 10.1353/tech.2014.0067.

[10] R. Zhong, X. Xu, and L. Wang, "Food supply chain management: systems , implementations , and future research," Ind. Manag. Data Syst., vol. 117, no. 9, pp. 2085-2114, 2017, doi: 10.1108/IMDS-092016-0391.

[11] S. Suresh, A. Chaudhary, B. Mathur, and D. Gupta, "A Literature review on Investigation of Supply Chain Quality issues / constructs in Agri-fresh Supply Chain," Int. J. Adv. Res. Sci. Eng., vol. 6, no. 2, pp. 706-710, 2017, available at: https://www.ijarse.com/images/fullpdf/15 14974056_IE04-011.pdf. 
[12] M. Zhang and P. Li, "RFID Application Strategy in Agri-Food Supply Chain Based on Safety and Benefit Analysis," Phys. Procedia, vol. 25, pp. 636-642, 2012, doi: 10.1016/j.phpro.2012.03.137.

[13] Y. Lemma, D. Kitaw, and G. Gatew, "Loss in Perishable Food Supply Chain: An Optimization Approach Literature Review," Int. J. Sci. Eng. Res., vol. 5, no. 5, 2014, available at: Google Scholar.

[14] M. M. Siddh, G. Soni, and R. Jain, "Agrifresh food supply chain quality ( AFSCQ): a literature review Industrial Management \& Data Systems Article information:," Ind. Manag. Data Syst., vol. 117, no. 8, pp. 2015-2044, 2017, doi: 10.1108/IMDS-102016-0427.

[15] B. Derqui, T. Fayos, and V. Fernandez, "Towards a More Sustainable Food Supply Chain: Opening up Invisible Waste in Food Service," Sustainability, vol. 8, no. 7, p. 693, Jul. 2016, doi: 10.3390/su8070693.

[16] F. Rizqiah and A. S. Slamet, "Analisis Nilai Tambah dan Penentuan Metrik Pengukuran Kinerja Rantai Pasok Pepaya Calina (Studi Kasus di PT Sewu Segar Nusantara)," J. Manaj. dan Organ., vol. 5, no. 1, p. 71, May 2016, doi: 10.29244/jmo.v5i1.12120.

[17] A. Hidayati and P. R. Kurnia, "Strategi Pemasaran Produk Pepaya Sunfresh Jenis California Grading B dan C di Pasar Tradisional Kawasan Jabotabek 20122014," J. Manag. Bus. Rev., vol. 9, no. 1, Feb. 2017, doi: 10.34149/jmbr.v9i1.77.

[18] Y. Handayati, T. M. Simatupang, and T. Perdana, "Agri-food supply chain coordination: the state-of-the-art and recent developments," Logist. Res., vol. 8, no. 1, pp. 1-15, Dec. 2015, doi: 10.1007/s12159-015-0125-4.

[19] C. Rota, N. Reynolds, and C. Zanasi, "Sustainable food supply chains: the role of collaboration and sustainable relationships," Int. J. Bus. Soc. Sci., vol. 4, no. 4, pp. 45-53, 2013, available at: http://ijbssnet.com/journal/index/1850.

[20] B. Nitsche, J. Kleineidam, F. Straube, and M. Meißner, "Systematization and discussion of the current state of waste management in food supply chains," $J$. Japanese Oper. Manag. Strateg., vol. 8, no. 1, pp. 1-17, 2018, doi: 10.20586/joms.8.1_1.

[21] R. Price, "Product protection," Food Drink Technol., vol. 14, no. 10, p. 35, 2015, available at: Google Scholar.

[22] M. Jeong, D. S. An, S. J. Lee, and D. S. Lee, "The Quality of King Oyster Mushrooms Stored with a Master Packaging System Consisting of Inner Individual Packs and an Outer Liner Bag to Be Dismantled at a Retail Display," Food Sci. Technol. Res., vol. 18, no. 4, pp. 535541, 2012, doi: 10.3136/fstr.18.535.

[23] D. Dainelli, N. Gontard, D. Spyropoulos, E. Zondervan-van den Beuken, and P. Tobback, "Active and intelligent food packaging: legal aspects and safety concerns," Trends Food Sci. Technol., vol. 19, pp. S103-S112, Nov. 2008, doi: 10.1016/j.tifs.2008.09.011.

[24] M. Vanderroost, P. Ragaert, F. Devlieghere, and B. De Meulenaer, "Intelligent food packaging: The next generation," Trends Food Sci. Technol., vol. 39, no. 1, pp. 47-62, Sep. 2014, doi: 10.1016/j.tifs.2014.06.009. 